\title{
Microbiological assessment of sewage sludge hygienization in the process of composting with the use of Salmonella Enteritidis
}

\author{
Katarzyna Budzińska ${ }^{1,}{ }^{*}$, Magdalena Michalska ${ }^{1}$, and Bożena Szejniuk $^{1}$ \\ ${ }^{1}$ UTP University of Science and Technology, Faculty of Animal Breeding and Biology, Department of \\ Animal Hygiene and Microbiology of the Environment, Mazowiecka 28, 85-084 Bydgoszcz, Poland
}

\begin{abstract}
The aim of the study is to assess effectiveness of sewage sludge composting efficiency on the basis of survival of Salmonella Enteritidis bacteria. Carriers containing a strain of $S$. Enteritidis were added to three layers of a compost pile made of dehydrated sewage sludge from a mechanical-biological wastewater treatment plant and wheat straw. The maximum time of the bacteria survival was established which was found to be the longest in the bottom part of the heap and was 58 days, whereas in the top layer of the pile the survival time of the microorganisms was the shortest, which is 49 days. In the thermophilic stage the highest generated temperatures were from 66 to $73^{\circ} \mathrm{C}$ for a period of 7 days. It found reflection in the fastest rate of Salmonella bacilli inactivation. A thermophilic stage was also found in the middle layer of the pile which lasted for 5 days throughout which period the temperature ranged from 66 to $72^{\circ} \mathrm{C}$. Temperatures in the bottom part of the pile were found to be lower, from 30 to $61^{\circ} \mathrm{C}$, whereas temperature above $60^{\circ} \mathrm{C}$ was reported only for 2 days.
\end{abstract}

\section{Introduction}

Sewage sludge is characterized by a significant content of organic matter, macro- and micro-components which make it suitable to be used for fertilization of rural and forest areas and recultivation of green areas [1]. However, apart from many beneficial effects making it a good fertilizer, there are also some drawbacks including occurrence of intestinal parasites. Bacteria account for a significant amount of microorganisms settling sewage sludge with prevailing Enterobacteriaceae. According to literature Salmonella bacillus belong to pathogenic bacteria that most frequently occur in sewage sludge. Stroczyńska-Sikorska [2] says that Salmonella bacteria occurs in 100\% of raw sludge samples and in $41 \%$ of digested sludge. Kłapeć and Cholewa [3] isolated Salmonella bacillus in $62 \%$ of the samples with digested sludge. The biggest amount of microbiological contamination is found in domestic wastewater where pathogenic microorganisms infiltrate human and animal waste. It is thought that about $0.5-5.0 \%$ of human population is infected by sewage sludge. When assessing a sanitary state of

\footnotetext{
* Corresponding author: kasiabud@utp.edu.pl
} 
a sewage sludge, the period of microorganism survival in given environmental conditions as well as the rate of their cell dying, need to be considered. The time of pathogenic microorganism survival outside the host's organism is affected by many factors including: temperature, sun exposure, $\mathrm{pH}$ and moist [4]. Long survival of most pathogenic microorganisms is a significant problem connected with biological sewage sludge management, especially its agricultural utilization, where these organisms are able to survive in the soil or plants for months and even years $[5,6]$. For this reason, the sewage sludge needs to undergo the process of hygienization before it can ever be used [7]. Composting of sewage sludge is one of the methods of biodegradable waste neutralization. Due to a rich content of organic substances in domestic wastewater, this method should have priority over other forms of waste management such as landfills or incineration [8]. Agricultural management of sewage sludge is most beneficial for small and medium wastewater treatment plants and those which are located in rural areas. Sewage sludge that comes from such facilities is characterized by low content of heavy metals, so they can be composted without any problems and later used for fertilization [9]. Regardless of the sewage sludge source, the process of composting involves processing of organic matter in the conditions of oxygen and interaction of pathogenic microorganisms to obtain a stable, safe and pathogens free fertilizer [10]. Assessment of efficiency of sewage sludge hygienization in the process of composting involves determination of inactivation dynamics for indicator bacteria that is Salmonella, Escherichia coli and Streptococcus faecalis. The survival time of microorganisms in composted sewage sludge depends, among others, on the input concentration and on the kind of composting technology. Thus, it is important to turn the pile to cause replacement of the compost layers. Temperature is a factor that has a large influence on the process of composting as it boosts activeness and diversity of microorganisms. Monitoring its changes allows to control the process of matter decomposition in the compost piles [11]. According to Marcinkowski [12] alkaline environment is a factor that causes deactivation of Salmonella type bacteria. The goal of the research was to assess efficiency of sewage sludge composting on the basis of Salmonella Enteritidis survival.

\section{Material and methods}

An isolated pile was built on a hardened floor of a wastewater treatment plant inside of which perforated pipes were placed to collect the sewage. The compost pile was built from dehydrated sewage from mechanical-biological treatment plant. Wheat straw, cut into $15 \mathrm{~cm}$ long sections, was also added to enhance the structure. Particular components were mixed in proportion 1:1. Dimensions of compost pile and distribution of carriers containing bacteria Salmonella Enteritidis was presented on the Figure 1.

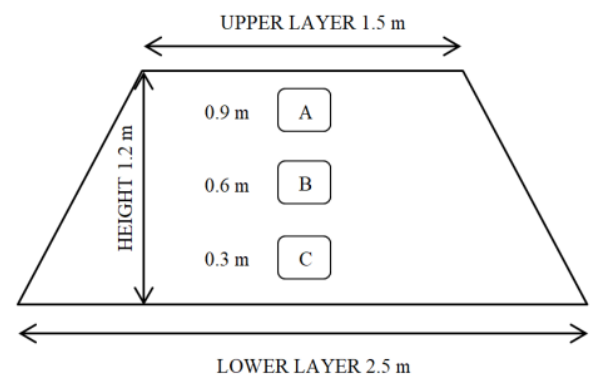

Fig. 1. Scheme of compost pile and distribution of carriers containing bacteria Salmonella Enteritidis (A - top; B - middle; $\mathrm{C}$ - bottom ). 
The experiment involved mechanical aeration by turning the composting mixture in time intervals dependent on the stage of composting. In the first and the second week of the experiment the pile was aired every day, whereas later, the biomass was turned 2 times a week. After the sixth week of the experiment the pile was not aired as it entered the process of maturation. In order to determine the impact of sewage sludge composting on elimination of indicator bacteria Salmonella Enteritidis ATCC 13076 strain was used. Carriers for tested bacteria were prepared by mixing $1500 \mathrm{~g}$ of dehydrated sewage sludge with $150 \mathrm{~g}$ of cut straw. In the next stage a suspension containing Salmonella Enteritidis bacteria was prepared and its density was established as $9.0 \cdot 10^{8}$ cells $/ \mathrm{ml}$ by using an optical densitometer (Vitek Systems ATB 1550). $100 \mathrm{ml}$ of suspension with indicator bacteria was implemented into mixed sewage sludge with straw and placed in 30 perlon bags with dimensions of 7 to $10 \mathrm{~cm}$. The carriers were placed in a pile in the top, middle and bottom layers (Fig. 1). Carries with Salmonella Enteritidis were collected from individual layers of a compost pile for a period of 60 days. Measurements of $\mathrm{pH}$ were performed for all the three levels of the pile. Temperature and dry matter content were measured throughout the experiment. The $\mathrm{pH}$ value of the composted material was determined with the potentiometric method in the prepared suspension according to the PN-EN 12176. Dry matter was examined according to the recommendations of PN-EN 15934:2013-02. Temperature of the composted biomass was measured at three levels of the pile throughout the period of the study, using a digital agricultural thermometer with a probe.

Marking the number of indicator bacteria was performed by the MPN method (most probable number). The first stage of Salmonella bacilli identification involved proliferation in $1 \%$ buffered peptone water (incubation in temperature $37^{\circ} \mathrm{C}$ for $24 \mathrm{~h}$ ). Next, motility of a given strain was measured using a semi-liquid selective substrate acc. to Rappaport Vassiliadis Modified Semi-Solid Medium with the use of supplement novobiocin (MSRV). Selective proliferation was performed in a liquid culture, according to Rappaport Vassiliadis with addition of tetrathionate and malachite green (incubation in temperature $41^{\circ} \mathrm{C}$ for $24 \mathrm{~h}$ ). The next stage involved replacing the culture onto an agar substrate BPLA with brillantine green, phenol red and lactose and onto agar substrate XLD with xylose, lysine and deoxycholate. Incubation was carried out in temperature $37^{\circ} \mathrm{C}$ for $24 \mathrm{~h}$. The last stage involved applying serological (reactions with serum HM) and biochemical tests (microtest API 20E).

The results of the tests of Salmonella Enteritidis bacteria survival in compost sewage sludge were verified, the results were logarithmized and statistically analyzed on the basis of the analyzed bacteria number change in time, according to formula 1 :

$$
y=a x+b
$$

where: $y$ - logarithm of the number of indicator bacteria, $a$ - elimination of bacteria during one day, $b$ - number of bacteria in the zero stage, $x$ - time counted in days.

The basic statistical analysis was performed by means of Statistica program version 6.0 Microsoft Software and Microsoft Excel 2007.

\section{Results and discussion}

Changes in the number of Salmonella Enteritidis bacteria in particular layers of the compost sewage sludge pile throughout the experiment are shown in Table 1. On the first day of the experiment the amount of Salmonella Enteritidis bacteria was found to be similar in the whole pile from $9.0 \cdot 10^{8} \mathrm{cfu} / \mathrm{g}$ (lower layer) to $9.5 \cdot 10^{8}$ (top and middle layers). After 5 days of composting a slight decrease in the number of bacteria was reported. During the next 20 days of the composting process the amount of Salmonella Enteritidis bacteria was 
decreasing, whereas the fastest elimination of the bacteria cells was found for the top layer of the pile, where their number was reported to be at the level of $2.5 \cdot 10^{6} \mathrm{cfu} / \mathrm{g}$. In the same period dead bacteria of the middle part of the pile were isolated in the amount of $1.5 \cdot 10^{7} \mathrm{cfu} / \mathrm{g}$, whereas from the bottom layer $2.5 \cdot 10^{6} \mathrm{cfu} / \mathrm{g}$. El-Housseinim [13] reported a very low amount of Salmonella as early as within 4 weeks of the composting process duration. Between 28 and 70 days of the experiment the amount of these bacteria did not exceed the level $10^{1} \mathrm{cfu} / \mathrm{g}$. After 8 weeks, the author did not isolate the bacteria any more. In the authors' own experiments the first rapid drop in the number of Salmonella Enteritidis of the composted mass was reported on the 30th day of the experiment for the top layer of the pile by $4.58 \mathrm{log} \mathrm{cfu} / \mathrm{g}$, in relation to the input concentration. In the middle layer of the pile, bacteria were found to be dying at a slower rate where the drop was $3.32 \mathrm{log} \mathrm{cfu} / \mathrm{g}$. However, the lowest elimination level was reported for the bottom layer of the pile where the drop was $2.56 \mathrm{log} \mathrm{cfu} / \mathrm{g}$ in relation to the initial value. After the next 9 days of the experiment Salmonella Enteritidis bacteria were isolated from the carriers in the amount of, respectively: $9.5 \cdot 10^{1} \mathrm{cfu} / \mathrm{g}$ (top); $1.5 \cdot 10^{2} \mathrm{cfu} / \mathrm{g}$ (middle) and $2.0 \cdot 10^{3} \mathrm{cfu} / \mathrm{g}$ (bottom). In the 43rd day of the experiment bacteria were isolated only from the carriers o the bottom layer of the pile, whereas in the $50^{\text {th }}$ and $60^{\text {th }}$ day no bacteria of this kind were not found in the composted sewage sludge.

Table 1. Number of Salmonella Enteritidis in particular layers of the pile.

\begin{tabular}{|c|c|c|c|c|c|c|}
\hline \multirow{2}{*}{ Research days } & \multicolumn{2}{|c|}{ Top layer } & \multicolumn{2}{c|}{ Middle layer } & \multicolumn{2}{c|}{ Bottom layer } \\
\cline { 2 - 7 } & $\mathrm{cfu} / \mathrm{g}$ & $\log \mathrm{cfu} / \mathrm{g}$ & $\mathrm{cfu} / \mathrm{g}$ & $\log \mathrm{cfu} / \mathrm{g}$ & cfu/g & $\log \mathrm{cfu} / \mathrm{g}$ \\
\hline 1 & $9.5 \cdot 10^{8}$ & 8.97 & $9.5 \cdot 10^{8}$ & 8.97 & $9.0 \cdot 10^{8}$ & 8.95 \\
\hline 5 & $1.5 \cdot 10^{8}$ & 8.17 & $9.5 \cdot 10^{8}$ & 8.97 & $1.5 \cdot 10^{8}$ & 8.17 \\
\hline 12 & $2.0 \cdot 10^{7}$ & 7.30 & $7.5 \cdot 10^{7}$ & 7.87 & $4.5 \cdot 10^{8}$ & 8.10 \\
\hline 20 & $4.5 \cdot 10^{6}$ & 6.65 & $9.5 \cdot 10^{7}$ & 7.97 & $2.5 \cdot 10^{8}$ & 8.39 \\
\hline 25 & $2.5 \cdot 10^{6}$ & 6.39 & $1.5 \cdot 10^{7}$ & 7.17 & $2.5 \cdot 10^{6}$ & 6.39 \\
\hline 30 & $2.5 \cdot 10^{4}$ & 4.39 & $4.5 \cdot 10^{5}$ & 5.65 & $2.5 \cdot 10^{6}$ & 6.39 \\
\hline 39 & $9.5 \cdot 10^{1}$ & 1.97 & $1.5 \cdot 10^{2}$ & 2.17 & $2.0 \cdot 10^{3}$ & 3.30 \\
\hline 43 & 0 & 0 & 0 & 0 & $1.0 \cdot 10^{2}$ & 2.00 \\
\hline 50 & 0 & 0 & 0 & 0 & 0 & 0 \\
\hline
\end{tabular}

The carried out regression analysis allowed to establish the rate of elimination and theoretical maximal time of the indicator bacteria survival in the composted sewage sludge (Fig. 2-4). Prognostic tests showed that the highest rate of Salmonella Enteritidis cells dying were found for the top and middle layers of the compost pile at the level of $0.20 \log \mathrm{cfu} /$ day, whereas in the bottom layer of the pile the daily rate of the bacteria inactivation was marked to be $0.18 \log$ cfu. Bauza-Kaszewska and Paluszak [14] found that the rate of Salmonella bacteria elimination depends on the layer of the pile and the composting temperature. The highest inactivation rate was reported for the middle layer of the pile where the bacteria cells died before the end of three weeks. A variable rate of Salmonella senftenberg W775 bacteria elimination in composted sewage sludge also depends on the applied technology of aeration [14]. According to these authors Salmonella senftenberg W775 bacteria, added to an experimental pile in a concentration of $9.15 \cdot 10^{7} \mathrm{cfu} / \mathrm{g}$ in an object with mechanical aeration involving turning the mass after 20 days, disappeared from the middle layer, whereas, after 34 days from the top layer and after 41 days from the bottom layer. The authors of the study established, on the basis of regression equations, that the maximal survival time of Salmonella Enteritidis bacteria, was found to be the longest in the bottom part of the pile and was 58 days (Fig. 4), whereas the shortest time of survival was found for the top layer 49 days (Fig. 2). The results obtained by Budzińska [15] during composting of sewage sludge oscillated at a similar level. For a material with bacteria carriers whose initial concentration was $9.5 \cdot 10^{8} \mathrm{cfu} / \mathrm{g}$, the 
theoretical, maximal survival time of Salmonella senftenberg in the top layer of the pile was 48.37 days, in the middle part it was 49 days and in the bottom part 55.3 days.

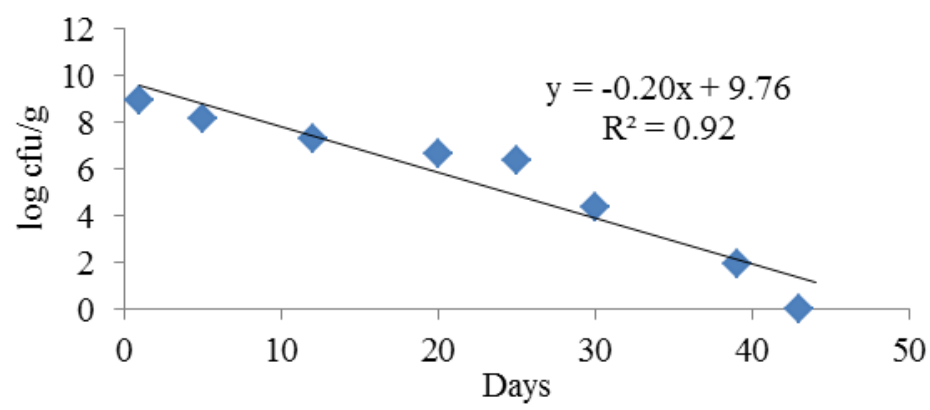

Fig. 2. Regression lines characterizing a drop in the number of Salmonella Enteritidis in the top layer of the compost pile.

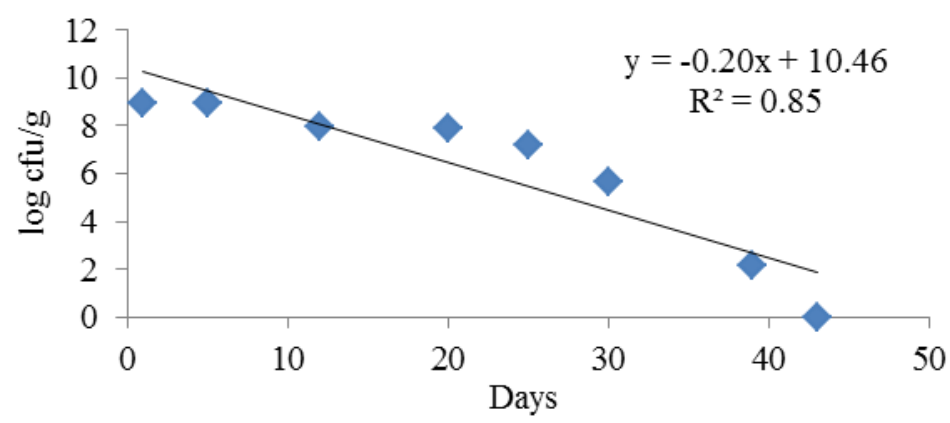

Fig. 3. Regression lines characterizing a drop in the number of Salmonella Enteritidis in the middle layer of the compost pile.

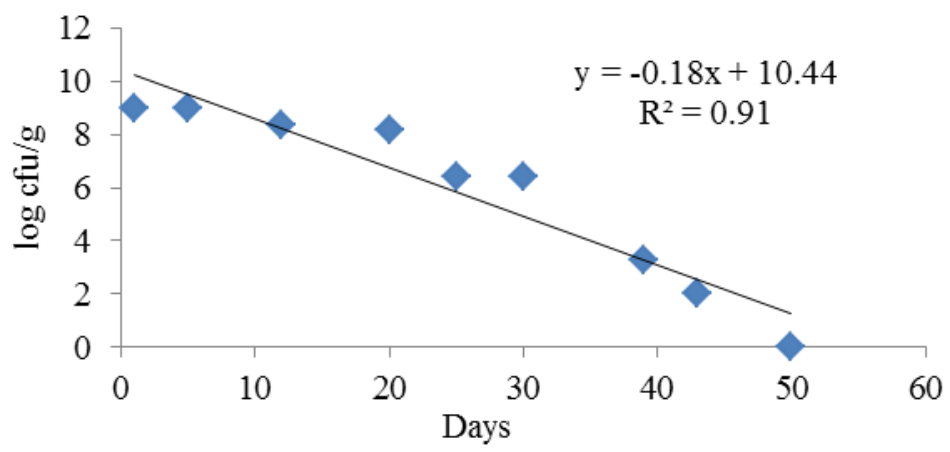

Fig. 4. Regression lines characterizing a drop in the number of Salmonella Enteritidis in the bottom layer of the compost pile.

The main factors determining elimination of pathogenic bacteria in the composted material include: the pile temperature which exerts a significant influence on the sanitaryhygienic state of the obtained compost $[16,17]$. According to the results of the authors' own research, in the first period of composting, the temperature was low in all layers of the pile. 
From 1 to 15 day of the experiment the temperature of the top layer increased from 11 up to $22^{\circ} \mathrm{C}$. In this composting stage, temperatures in the middle and the bottom parts of the pile were slightly different, respectively, $9-18^{\circ} \mathrm{C}$ and $10-18^{\circ} \mathrm{C}$. Such an arrangement of temperatures in this period of experiment can be explained by a slight decrease in the number of Salmonella Enteritidis in the carriers introduced to particular layers of the pile. A significant growth of temperature was found in the top layer from 16 to 38 day of the experiment, where temperatures between 40 and $73^{\circ} \mathrm{C}$ were reported. It needs to be emphasized that, in the thermophilic stage of composting, the highest temperatures in the pile were from 66 to $73^{\circ} \mathrm{C}$, for the period of 7 days. This found reflection in the highest inactivation rate of Salmonella bacilli. A thermophilic stage was also reported for the middle part of the pile, which lasted for the period of 5 days, where the temperature ranged at the level of $66-72^{\circ} \mathrm{C}$. In the bottom part of the pile there were lower temperatures ranging from 30 to $61^{\circ} \mathrm{C}$, whereas the temperature above $60^{\circ} \mathrm{C}$ was reported only for two days. In the $90^{\text {th }}$ day of composting, Wolna-Maruwka and Czekała [18] found no Salmonella bacilli. Such an output was possible for the biological material due to its reaching the thermophilic stage $\left(60^{\circ} \mathrm{C}\right)$. Lack of a thermophilic stage has a direct impact on prolongation of the studied microorganism inactivation time whose survival increases under such conditions. In order to obtain consistent and safe fertilizer to be used in agriculture the temperature in the pile needs to increase from 45 to $70^{\circ} \mathrm{C}$, which determines elimination of pathogenic microorganisms from the composted material [19]. It needs to be stressed that in the authors' own research, despite lower temperatures occurring in the bottom layer of the compost pile, the achieved temperatures enabled total elimination of indicator bacteria from the sewage sludge, though after a period longer by 9 days as compared to the top layer and by 6 days as compared to the middle layer (Fig. 5). Literature data indicates that, achievement of the sewage sludge full hygienization effect is possible after reaching temperature over $55^{\circ} \mathrm{C}$, which should maintain for the period of app. 3 weeks [10].

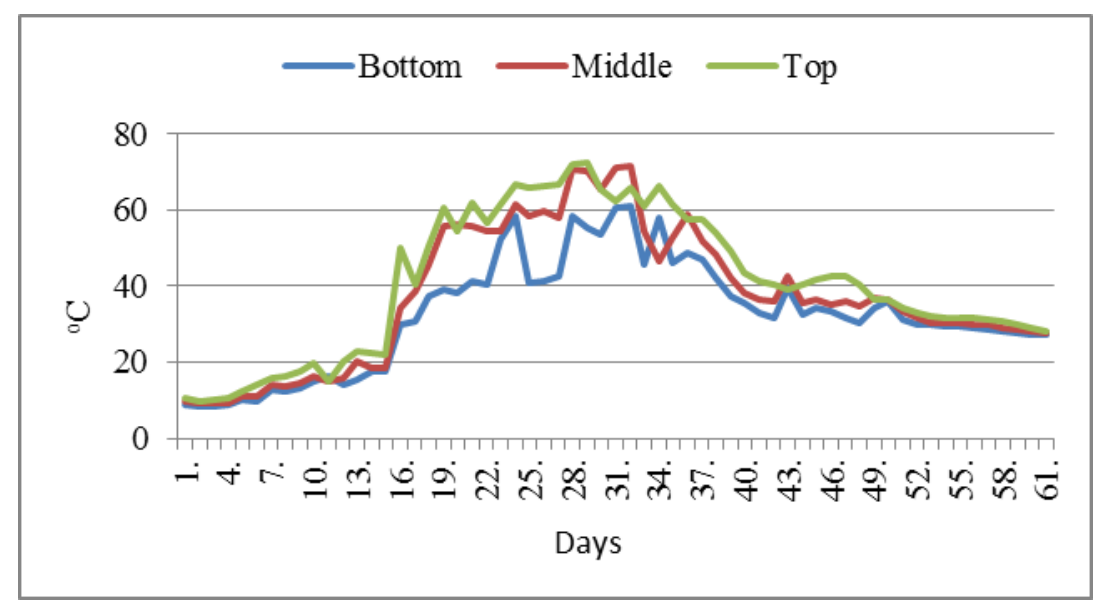

Fig. 5. Changes in temperature in the studied material during the composting process.

The content of dry matter and $\mathrm{pH}$ of the sewage sludge are factors that determine the process of composting. Dach and Zbytek [20] found out that the dry matter content ranged from 23.6 to $28.4 \%$, whereas $\mathrm{pH}$ was between 7.7 and 8.1. In turn, Siuta et al. [21] proved that for unlimited sewage sludge composting with straw addition the content of dry matter reached $35.5 \%$, whereas, for a limed sludge with straw addition it was $54 \%$. In the authors' own research, the dry matter content on the day of the experiment start, was $20.20 \%$ for the whole pile. The experiment was characterized by constant tendency of the pile dry matter 
increase which on the $12^{\text {th }}$ day of the experiment was the highest in the top layer of the pile at the level from $23.08 \%$, whereas, the lowest was $21.90 \%$ in the bottom layer. The content of dry matter was growing gradually while on the 43rd day of the sewage sludge composting, its significant growth was reported reaching $49.68 \%$ in the top part of the pile, whereas in the middle and bottom parts, it was respectively: 46.28 and $43.94 \%$. The highest contents of dry matter was found in the stage of the compost maturation, on the 60th day and for the top, middle and bottom layers they were, respectively: $56.34 \% ; 55.36 \%$; $50.15 \%$ (Table 2).

Table 2. Changes in dry matter share (\%) in the studied material during the composting process.

\begin{tabular}{|c|c|c|c|}
\hline Research days & Top layer & Middle layer & Bottom layer \\
\hline 1 & 20.20 & 20.20 & 20.20 \\
\hline 5 & 21.12 & 21.89 & 20.97 \\
\hline 12 & 23.08 & 22.10 & 21.90 \\
\hline 20 & 26.92 & 26.49 & 24.39 \\
\hline 25 & 27.23 & 27.33 & 26.77 \\
\hline 30 & 31.39 & 35.42 & 27.13 \\
\hline 39 & 36.41 & 40.98 & 40.61 \\
\hline 43 & 49.68 & 46.28 & 43.94 \\
\hline 50 & 55.36 & 54.00 & 49.94 \\
\hline 60 & 56.34 & 55.36 & 50.15 \\
\hline
\end{tabular}

The composting process is often accompanied with the $\mathrm{pH}$ changes which result, among others, from intensity of decomposition processes that occur inside the pile as well as from acids that are produced. The changes are small and usually, after a short, slight decrease, $\mathrm{pH}$ turns into the alkaline, which is the effect of ammonium release alkalinizing the environment. Additionally, composting of a sewage sludge involves presence of mineral and organic compounds which can cause periodic changes of the compost $\mathrm{pH}$ [22]. Table 3 shows $\mathrm{pH}$ changes in the composted biomass which at the beginning of the experiment ranged at a similar level in all layers of the pile and was similar to slightly alkaline $\mathrm{pH}$.

Table 3. Changes in the $\mathrm{pH}$ value in the studied material during the composting process.

\begin{tabular}{|c|c|c|c|}
\hline Research days & Top layer & Middle layer & Bottom layer \\
\hline 1 & 7.16 & 7.22 & 7.13 \\
\hline 5 & 7.76 & 7.98 & 7.69 \\
\hline 12 & 7.88 & 7.99 & 7.83 \\
\hline 20 & 8.42 & 8.24 & 8.23 \\
\hline 25 & 8.30 & 8.36 & 8.11 \\
\hline 30 & 8.25 & 8.39 & 8.00 \\
\hline 39 & 8.18 & 8.20 & 7.90 \\
\hline 43 & 7.49 & 7.50 & 7.40 \\
\hline 50 & 7.06 & 7.11 & 6.90 \\
\hline 60 & 7.07 & 7.10 & 6.99 \\
\hline
\end{tabular}

In the first three weeks of composting the experiments revealed $\mathrm{pH}$ increase up to 8.42 in the upper part of the pile, up to 8.23 in the bottom part, after which a slow drop in $\mathrm{pH}$ value was reported for all the pile layers. In the 60th day of the experiment $\mathrm{pH}$ of the composted sewage sludge was 6.99 to 7.10. Wolna-Maruwka and Pilarski [11] obtained results similar to those achieved by the authors. The contents of dry matter and $\mathrm{pH}$ obtained in the authors' own experiment were typical for a normal process of sewage sludge composting [23]. In conclusion, it needs to be said that the process of composting has a destructive impact on pathogenic microorganisms inhabiting in sewage sludge. Due to the impact of various environmental factors, pathogenic microorganisms are being slowly 
eliminated during the composting process, whereas the dynamics of changes can be characterized by high diversification [24, 25].

\section{Conclusions}

The experiments have shown effectiveness of the process of sewage sludge composting for elimination of Salmonella Enteritidis bacteria. The experiments have proved that the most important parameter providing achievement of the sanitary safest compost is temperature which in the thermophilic stage depends on the pile layer. The composting process is affected by the content of dry matter and $\mathrm{pH}$ of the sewage sludge. The obtained results have proved that the total elimination of Salmonella Enteritidis bacteria from the composted biomass was possible after 58 days of the process duration.

\section{References}

1. J. Kaniuczak, E. Hajduk, J. Zamorska, M. Ilek, Zesz. Nauk. PTG 11, 89 (2009)

2. M. Stroczyńska-Sikorska, Ocena wpływu nawozów na ludzi. Raport BIP 2, 83 (2006)

3. T. Kłapeć, A. Cholewa A., Med. Og. Nauk. Zdr. 18, 131 (2012)

4. O. Kosarewicz, J. Firlus, G. Uniejowska, GWiTS 76, 292 (1999)

5. E. Bagge, L. Sahlström, A. Albihn, Water Res. 39, 4879 (2005)

6. K. Budzińska, A. Jurek, Ekologia i Technika 10, 58 (2002)

7. M. Kaźmierczuk., L. Kalisz, Ochr. Śr. Zasobów Nat. 42, 183 (2010)

8. Cz. Rosik-Dulewska, Podstawy gospodarki odpadami (Państwowe Wydawnictwo Naukowe, Warszawa, 2010)

9. H. Bauman-Kaszubska, M. Sikorski, Inż. Ekolog. 25, 20 (2011)

10. J. Bauza-Kaszewska, Z. Paluszak, K. Skowron, Woda-Środowisko-Obszary Wiejskie 30, 19 (2010)

11. A. Wolna-Maruwka, K. Pilarski, Ochr. Śr. Zasobów Nat. 42, 212 (2010)

12. T. Marcinkowski, Ochr. Śr. 25, 49 (2003)

13. M. El-Housseinim, Co-compost production from agricultural wastes and sewage sludge, 17th WCSS. Soils, Water and Environment Research Institute, ARC Egypt (2002)

14. J. Bauza-Kaszewska, Z. Paluszak, Zesz. Nauk. AR. Wrocław. Zootechnika 501, 13 (2004)

15. K. Budzińska, Zesz. Nauk. AR. Wrocław, Zootechnika 505, 61 (2004)

16. A. Hassen, K. Belguht, N. Jedidi, M. Cherif, A. Boudabous, EPCOWM 357 (2002)

17. L.B. Taiwo, B.A. Oso, Afr. J. Biotechnol. 3, 239 (2004)

18. A. Wolna-Maruwka, J. Czekała, Arch. Environ. Prot. 33 (4), 53 (2007)

19. G. Hamer, Biotechnol. Adv. 22, 71 (2003)

20. J. Dach, Z. Zbytek, J. Res. Appl. Agric. Eng. 50, 24 (2005)

21. J. Siuta, L. Dusik., W. Lis, Inż. Ekolog. 19, 97 (2007)

22. J. Czekała, Chemical proprieties of a compost produced on the basis of sewage sludge and different biowaste. J. Res. Appl. Agric. Eng. 53, 35 (2008)

23. E. Krzywy, S. Baran, J. Krzywy, Inż. Ekolog. 7, 66 (2002) 
24. K. Budzińska, A. Jurek, M. Michalska, K. Berleć, Zesz. Prob. Post. Nauk Rol. 506, 103 (2005)

25. J. Wiater, A. Butarewicz, Inż. Ochr. Śr. 17, 281 (2014) 